\title{
CASE Study: Economic viability of producing animal bedding from low quality and small diameter trees using a wood shaving machine
}

\author{
Matthew M. Smith, ${ }^{1}$ John D. Aber, and Theodore E. Howard \\ Department of Natural Resources, University of New Hampshire, Durham 03824
}

\begin{abstract}
This study explores the feasibility of producing animal bedding using a wood shaving machine fed with low quality and small diameter trees. An economic decision model was created, allowing individuals to input site and machinespecific parameters into the model. Model output provides data for 2 scenarios. Scenario 1 explores whether a farmer could support this venture by producing bedding for onfarm consumption only. Scenario 2 explores the profit an individual (farmer or nonfarmer) could gain if operating the wood shaving machine for 8 to $40 \mathrm{~h} /$ wk throughout the year. Model output for scenario 1 found that the average-sized organic and conventional dairy farm in New England would not be able to support this type of venture. Instead, the breakeven volume of bedding corresponded to farms with greater than 170 cows, indicating that larger farms, or a cooperative of locally clustered small farms using the machine collectively, would have a more favorable payback period. For scenario 2, the payback period was $>15 \mathrm{yr}$ if operating $8 \mathrm{~h} /$ wk to $561 \mathrm{~d}$ if operating $40 \mathrm{~h} /$ wk throughout the year. The 15-yr net present value was $\$ 159,884$ to $\$ 1,777,435$ and the discounted benefit-cost ratio was 0.8 to 9.3 when operating 8 to $40 \mathrm{~h} /$ wk throughout the year. However, if operating $40 \mathrm{~h} /$ wk, supply may outweigh demand, as enough bedding could be produced for 30 organic or 25 conventional dairies of average size in the New England region.
\end{abstract}

Key words: animal bedding production, wood shaving machine, using low quality and small diameter trees, wood shavings

\section{INTRODUCTION}

From 2003 to 2013 the real cost of animal bedding increased by $71 \%$ for dairy farmers across the New England region (Smith et al., 2017). Cost increases were largely driven by a shortage of woody bedding from regional sawmills. Historically, these sawmills provided inexpensive

The authors declare no conflict of interest.

${ }^{1}$ Corresponding author: m.smith@unh.edu woody bedding (sawdust and planer shavings) as a byproduct of the milling process (Thomas and Schumann, 1993). However, the collapse in the new home construction market in 2005 and the recession of 2007 to 2009 resulted in the closing of a large fraction of the region's sawmills (Woodall et al., 2012). Bedding supply was further limited due to increases in mill efficiency and modernization, which reduced the amount of waste in the milling process. Increased efficiency and modernization for some mills also meant redirecting their entire wood waste stream to a wood-fired boiler to power their dry kilns, further reducing bedding availability. With $97 \%$ of New England dairy farmers using some fraction of woody bedding (Smith et al., 2017), few could avoid the increased costs.

However, one option that may reduce bedding costs is to use low quality or small diameter trees to produce bedding using a wood shaving machine. Unfortunately, information on the economics, management requirements, and general feasibility of producing bedding from forest products is absent from the academic and extension literature. Instead, animal bedding production from forests is only mentioned briefly in the literature as a potential method to process low quality and small diameter trees (Thomas and Schumann, 1993; Lynch and Mackes, 2002), or a potential agroforestry practice (Basnyat and Bhattacharya, 2007; Mead and Smith, 2016), without providing specific details on feasibility.

With the cost of a wood shaving machine starting at roughly $\$ 50,000$, there is risk in starting this type of venture due to the lack of literature and resources regarding the actual feasibility of producing animal bedding using this strategy. Filling this knowledge gap is important because farmers in forested regions, whether dairy, equine, poultry, or swine, could benefit from a new source of bedding material. Likewise, those in the forestry industry could benefit by finding a new revenue stream for low quality and small diameter trees. For these reasons, the New Hampshire Agricultural Experiment Station purchased a wood shaving machine for use at the University of New Hampshire (UNH) Organic Dairy Research Farm (ODRF) to determine the feasibility of this type of venture. The objectives of this study were to (1) develop an economic decision model that allows individuals to input site and machine-specific information to determine the 
feasibility of producing bedding at their site, (2) use the model to predict the economics of producing bedding for the average-sized New England organic and conventional dairy farm, (3) use the economic model to forecast the revenue an individual (farmer or nonfarmer) could generate if using the wood shaving machine for 8 to $40 \mathrm{~h} / \mathrm{wk}$, and (4) provide operational recommendations to those interested in pursuing this type of venture.

\section{MATERIALS AND METHODS}

\section{Research Site}

The UNH ODRF was selected as the location for the research project because the farm milks 50 cows, which is very close to the New England average of 53 cows for an organic dairy (McBride and Greene, 2009). The farm also has a 49-ha (120-acre) woodlot, with large quantities of low quality eastern white pine (Pinus strobus). Most of the trees that were harvested and used from the farm woodlot during the 3 -yr study were in the 10 - to $25-\mathrm{cm}$ (4- to 10 inch) size class. Larger diameter pine that were weeviled were also used. This farm was also selected for the project because eastern white pine shavings were already being used as bedding, allowing for an easy transition from purchased bedding to material being produced on site.

\section{Wood Shaving Machine and Accessories}

After review of several different wood shaving machine companies and models, the research team, along with the New Hampshire Agricultural Experiment Station, decided to purchase a trailer-mounted Tremzac 248T (St-Bonaventure, Quebec, Canada) with a built-in diesel engine (Figure 1).

The diesel engine model was selected over a power takeoff-driven version to avoid competition for tractor time during the summer months, when most of the tractors

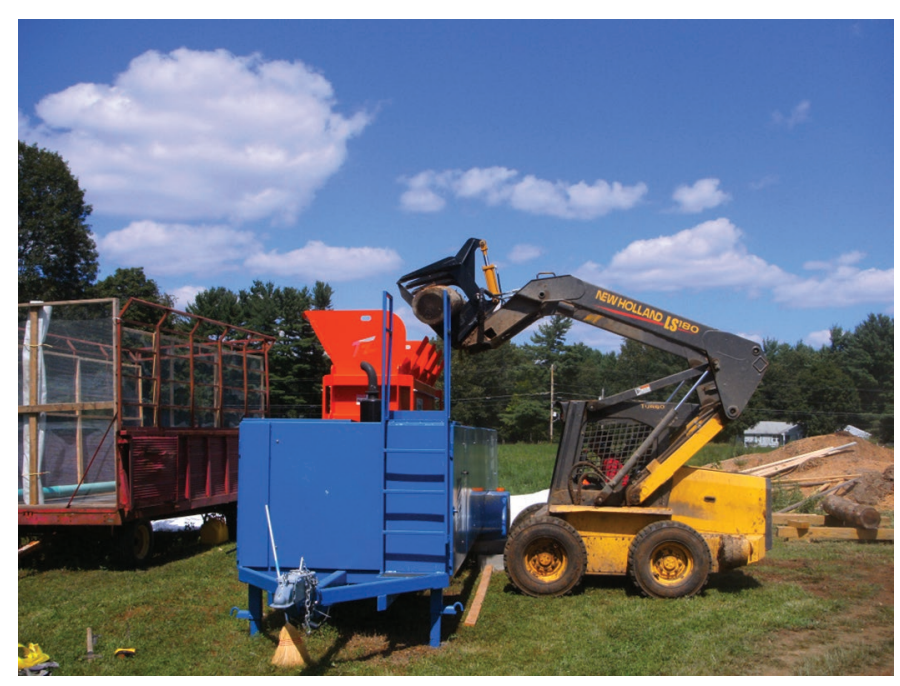

Figure 1. University of New Hampshire wood shaving machine being loaded. Color version available online. are used for forage management. The machine was also selected because it could handle 2.4-m (8-foot) logs up to $61 \mathrm{~cm}$ (24 inches) in diameter. In addition to the wood shaving machine, a 6-tine Sidney Gorilla Grapple skid steer attachment (Sidney Attachments, Lenexa, KS) was purchased to load the logs into the machine hopper. Total equipment cost was $\$ 60,850$.

\section{Wood Shaving Machine Financial Decision Model}

The financial decision model was created using Microsoft Excel. Excel was used for ease of model creation and accessibility for farm and forestry stakeholders. Model parameters were developed from operational experience from $3 \mathrm{yr}$ of using the wood shaving machine (2014 to 2016), ensuring all possible costs were included. The $3 \mathrm{yr}$ of operational experience also allowed for the creation of a model capable of handling site and machine-specific variabilities.

The final decision model had 24 input parameters (Table 1). When considering the 24 parameters, the model requires some values to be left blank. For instance, if using a power takeoff-powered machine, the model informs the individual to leave parameters 11 (energy consumption if using an electric machine) and 12 (cost/kWh for electricity) blank. The model also has specific instructions below each parameter, guiding the individual on how to properly fill in the information. The model also comes with a Parameter Definitions and Model Calculations tab within the Excel file, providing further information on (1) conversion factors to get into the right units for use in the model, (2) background calculations for how the model works, (3) troubleshooting procedures should something not work, and (4) links to various information sources to assist in filling out the model. [Individuals interested in the wood shaving machine model are encouraged to contact the lead author of this case study (Matthew M. Smith), who will send the most up-to-date version of the model via email. Please send inquiries to Matthew Smith at NHsurfer1021@ gmail.com or ms7@wildcats.unh.edu.]

\section{Background Model Calculations}

After inputting the 24 parameter values, background equations in Excel provide a range of output data. Of the background calculations, 3 necessitate explanation, because alternative methods could have been used in calculating these values. The first background calculation relates to how depreciation was calculated. In this model, straight line depreciation was selected using the following equation:

$$
\begin{gathered}
\text { Depreciation }=(\text { Cost of Machine }- \text { Salvage Value }) / \\
\text { Useful Life of Asset in Years. }
\end{gathered}
$$

For this equation, the salvage value was based on literature values for the average percent loss in equipment value due to age and wear of forestry equipment from the study 
by Cubbage et al. (1991). A literature value was used due to a lack of information regarding wood shaving machine purchases and sales, preventing a machine-specific assessment of salvage value. In the model, salvage value was based on equipment age ( 1 to $15 \mathrm{yr}$ ) and wear $(8,16,24$, 32 , and $40 \mathrm{~h} / \mathrm{wk}$ ).

The second background calculation relates to how the capital expenses (wood shaving machine, grapple, log loader, and so on) are financed. In this model, fixed rate financing was assumed, primarily due to the inability to forecast rate changes of a variable rate loan. The following fixed rate formula was used:

Fixed Rate Monthly Loan $c=r /\left[1-(1+r)^{-n}\right] \times p_{0}$,

where $r=$ monthly interest rate expressed as a fraction $(=$ $r / 100$ divided by 12 ); $n=$ loan's term (no. of years of loan $\times 12$ ); $p_{0}=$ loan principal (shaving machine, $\log$ loader, and so on); and $c=$ monthly payment.

The final background calculation of note is the expansion factor between solid wood and shavings. In this study, the expansion factor was determined experimentally, by comparing the average weight between wood shavings from fresh cut eastern white pine to that of solid wood from the same species. The weight of the wood shavings was based on filling a $0.03-\mathrm{m}^{3}$ (1-cubic-foot) box with 3-mmthick (0.125-inch-thick) shavings and obtaining an average weight. A shavings value of $118.9 \mathrm{~kg} / \mathrm{m}^{3}$ (7.4 pounds per cubic foot) was found and used for the model. The weight of solid eastern white pine wood was based on values from the literature. A value of $594.3 \mathrm{~kg} / \mathrm{m}^{3}$ (37.1 pounds per cubic foot) was used for the model (Coder, 2011). Based on these weights, an expansion factor of 5:1 was found between solid wood and shavings. The expansion factor resulted in a wood shavings-to-solid wood conversion factor of $8.4 \mathrm{~m}^{3}$ shavings per $1 \mathrm{Mg}$ of solid wood (10 cubic yards of shavings per ton or 15.7 cubic yards of shavings per cord of pulp wood). For reference, a cord is a unit of volume equivalent to 128 cubic feet $\left(3.62 \mathrm{~m}^{3}\right)$ and is a measurement common in the United States and Canada for the purchase of pulp wood, which is how wood shaving logs are classified in the region where the study took place.

\section{Model Output}

Output for the model is delivered for 2 different scenarios simultaneously, both of which report values on an annual basis and are pretax. The first scenario is for farmers looking to produce enough bedding for their farm, with no intention of selling material beyond that point. The second scenario explores the potential revenue an individual (farmer or nonfarmer) could make if operating the machine for $8,16,24,32$, or $40 \mathrm{~h} /$ wk. Output is presented in this manner to allow for situations where individuals have another full-time occupation and the wood shaving venture is for supplemental income.

Table 1. Parameters for economic decision model

\begin{tabular}{ll} 
Parameter & Description \\
\hline 1 & Machine make and model \\
2 & Power source (electric, diesel, power takeoff) \\
3 & Machine output rating adjusted for log loading $\left(\mathrm{m}^{3} / \mathrm{h}\right)$ \\
4 & Bedding requirement for farm $\left(\mathrm{m}^{3} / \mathrm{yr}\right)$ \\
5 & Current cost of bedding on farm $/ \mathrm{yr}$ \\
6 & Capital costs of project \\
7 & Interest rate of loan if financing the venture \\
8 & Loan period \\
9 & Fuel consumption for wood shaving machine $(\mathrm{L} / \mathrm{h})$ \\
10 & Cost of diesel/gallon \\
11 & Energy consumption if using an electric machine \\
12 & Regional cost/kWh for electricity \\
13 & Fuel consumption for material handing and log loading $(\mathrm{L} / \mathrm{h})$ \\
14 & Hourly wage per hour \\
15 & Number of workers receiving a wage \\
16 & Average cost of wood per cord \\
17 & Average cost of wood per megagram \\
18 & Local cost of blade sharpening per sharpening \\
19 & Cost of blade replacement \\
20 & Cost of routine maintenance per day \\
21 & Local cost for 1 m ${ }^{3}$ of air-dried green shavings \\
22 & Discount rate \\
23 & Depreciation period (yr) \\
24 & Salvage value factors \\
\end{tabular}


Outputs for these scenarios include wood requirement to meet operational demand (cords or tons), wood cost (cords or tons), labor cost for operating the machine, labor cost associated with setup and maintenance, fuel cost for log loading, fuel cost for machine operation (power takeoff, electric, or diesel), cost to sharpen knives, cost to purchase new knives, maintenance cost, depreciation, total operating cost, total fixed costs, cost to produce $0.76 \mathrm{~m}^{3}$ (1 cubic yard) of shavings, net revenue, and the implicit wage potential for the loan (if applicable) and postloan period. Output from this stage of the model is then used to calculate the project net present value (NPV), discounted benefit-cost ratio (BCR), and internal rate of return.

\section{Parameter Values Used in this Study}

Although the output from the decision model will vary between operators, the following parameters were used in this case study to illustrate (1) how the model works, (2) the economics of using a wood shaving machine to support the average-sized New England organic and conventional dairy farm, and (3) the economics of using a wood shaving machine based on machine usage (Table 2).

For reference, scenario 1 (on-farm production only) assumed a storage building would not be required to store the shavings, because one would likely exist on site al- ready. A delivery vehicle would also not be required. However, scenario 2 included both to account for the sale of the wood shavings. For the building, a 20-m-wide $\times$ 21-m-long (65-foot $\times 70$-foot) fabric structure at a cost of $\$ 62,400$ was added to parameter 6 in scenario 2. Additionally, a delivery dump truck with a $34-\mathrm{m}^{3}$ (45-cubic-yard) capacity was added to parameter 6 for a cost of $\$ 70,000$. The costs of the storage facility and transportation vehicle were based on quotes obtained from ClearSpan (South Windsor, CT) and USA Body (DeRuyter, NY).

\section{RESULTS AND DISCUSSION}

\section{Scenario 1: On-Farm Production Value Only}

The use of a wood shaving machine to produce animal bedding for on-farm purposes exclusively would not provide a positive economic return for most New England dairy farms because they do not have a high enough bedding demand to pay for the capital and operating costs of the machine. When using the case study farm, which represents the average-size New England organic dairy, bedding import costs would be offset by $\$ 10,500 /$ yr but would cost $\$ 20,181 / \mathrm{yr}$ in capital and operating costs to produce. This would result in an annual loss of $\$(9,618)$ during the 5-yr financing period. After the loan period,

Table 2. Parameter values

\begin{tabular}{|c|c|c|}
\hline Parameter & Description & Value \\
\hline 1 & Machine make and model & Tremzac $248^{1}$ \\
\hline 2 & Power source (electric, diesel, power takeoff) & Diesel \\
\hline 3 & Machine output rating adjusted for log loading $\left(\mathrm{m}^{3} / \mathrm{h}\right)$ & 7.6 \\
\hline 4 & Bedding requirement for farm $\left(\mathrm{m}^{3} / \mathrm{yr}\right)$ & 535 \\
\hline 5 & Current cost of bedding on farm $(\$ / y r)$ & 10,500 \\
\hline \multirow[t]{2}{*}{6} & Capital costs of project (scenario $1 ; \$)$ & 60,850 \\
\hline & Capital costs of project (scenario 2; \$) & 193,250 \\
\hline 7 & Interest rate of loan if financing the venture (\%) & 4.2 \\
\hline 8 & Loan period & 5 \\
\hline 9 & Fuel consumption for wood shaving machine $(\mathrm{L} / \mathrm{h})$ & 7.6 \\
\hline 10 & Cost of diesel $(\$ / L)$ & 0.61 \\
\hline 11 & Energy consumption if using an electric machine & 0 \\
\hline 12 & Regional cost/kWh for electricity & 0 \\
\hline 13 & Fuel consumption for material handing and log loading (L/h) & 3.8 \\
\hline 14 & Hourly wage per hour & 0 \\
\hline 15 & Number of workers receiving a wage & 0 \\
\hline 16 & Average cost of wood per cord & 0 \\
\hline 17 & Average cost of wood per megagram (\$) & 44 \\
\hline 18 & Local cost of blade sharpening per sharpening $(\$)$ & 100 \\
\hline 19 & Cost of blade replacement $(\$)$ & 800 \\
\hline 20 & Cost of routine maintenance per day $(\$)$ & 10 \\
\hline 21 & Local cost for $1 \mathrm{~m}^{3}$ of air-dried green shavings $(\$)$ & 19.6 \\
\hline 22 & Discount rate $(\%)$ & 4 \\
\hline 23 & Depreciation period (yr) & 15 \\
\hline 24 & Salvage value factors & $0.17-0.32$ \\
\hline
\end{tabular}

${ }^{1}$ St-Bonaventure, Quebec, Canada. 
Table 3. Financial performance if producing bedding for on-farm purposes only

\begin{tabular}{lc} 
Output description & Output value \\
\hline Loan period (\$) & \\
Cost/yr (fixed + operating) & 20,181 \\
Net revenue/yr & $-9,681$ \\
Implicit hourly wage & -127 \\
After the loan period (\$) & \\
Cost/yr (operating) & 6,684 \\
Revenue/yr & 3,816 \\
Implicit hourly wage & 50 \\
Project summary after 15 yr & $-8,198$ \\
Net present value (\$) & 0.14 \\
Discounted benefit-cost ratio & \\
\end{tabular}

the farm would save roughly $\$ 3,816$ per year with a 76 -h labor requirement, earning an implicit wage of $\$ 50 / \mathrm{h}$ for one worker. However, if assuming a 15-yr machine life, the balance of this operation would still be negative with a NPV of $(\$ 8,198)$ and a BCR of 0.14 (Table 3).

If using the same parameter values, the model calculates that the breakeven volume of wood shavings per year during the 5-yr loan period would be $1,893 \mathrm{~m}^{3}$ (2,476 cubic yards). Farms with bedding cost and volume equivalents less than these values would not cover capital and operating costs during the loan period. Although these parameters are specific to the university farm, this scenario illustrates a very important point - smaller farms, like the one used in this case study, will likely have a negative return during the loan period if they are only producing wood shavings for themselves. This is of concern because Smith et al. (2017) found that the average bedding usage per cow in New England was $11 \mathrm{~m}^{3} / \mathrm{yr}$ (14 cubic yards/yr). With the average number of cows per organic and conventional farm in New England being 53 (McBride and Greene, 2009) and 65 cows (USDA, 2012), respectively, the average annual bedding demand of $567 \mathrm{~m}^{3}$ (742 cubic yards) for organic and $697 \mathrm{~m}^{3}$ (910 cubic yards) for conventional dairies would not cover cost during a typical loan period.

Scenarios where on-farm production of bedding makes sense are on larger farms, where the payback period is less than 5 yr. Alternatively, a group of smaller but locally clustered farms could combine resources in a wood shaving cooperative to gain the benefits of a shared economy. With many of the small to mid-range wood shaving machines being trailer mounted, the machine could be transported from one farm to the other. Due to the high output from even the smaller machines, a small-scale dairy could produce enough bedding for a month in a 1- to 3 -d period. By way of example, the UNH ODRF has a $96-\mathrm{m}^{3}$ (125-cubicyard) storage bay in the barn for wood shavings that could be filled in $12 \mathrm{~h}$ of machine operation. With that in mind, a fairly large number of farms could be in the cooperative without having use conflicts. A survey study of animal bedding usage in New England by Smith et al. (2017) also found that regional dairy farmers were interested in wood shaving cooperatives, with $55 \%$ of their surveyed farmers showing interest in the venture. Of those interested, $79 \%$ were owners of farms with $\leq 99$ cows. Interestingly, farmers with $\geq 200$ cows had no interest in the cooperatives ( $0 \%$ interest).

In addition to sharing a machine through a cooperative, scenario 1 may become more feasible if farmers use wood from their own woodlot. The feasibility of this type of venture is entirely dependent on the size of the woodlot, species composition, age structure, and the time availability of the farmer. However, it is important to note that even if the species mix is not pine dominated, the farmer could do a volume swap with a local mill, where sawlogs from other tree species are sold, with the revenue being used to purchase low quality pine. This strategy was used in this study, because an economic analysis by the university's land use manager found that per hectare value of the woodlot would be greatest if all sawlogs were sold and a portion of the revenue was used to purchase low quality pine for animal bedding production. Furthermore, because of the large diameter pine in the woodlot, it was found that it was more economical to sell the first sawlog of each pine tree and use the lower-valued second and third logs in the wood shaving machine. By using this strategy, a single 0.4-ha (1-acre) patch cut provided enough biomass to support the annual bedding demand of the university dairy farm. With the average woodlot on dairy farms in New England being 64 ha (158 acres), this type of annual harvest could be sustained in the long term without concerns of overharvesting, as the rotation schedule would be $158 \mathrm{yr}$.

A final consideration that may increase the economics of the on-farm scenario pertains to the spent animal bedding and the ability to make compost. Composting operations, especially those on farms, are often nitrogen rich but carbon limited. However, farm operations using woody bedding would not likely have this issue and could produce compost derived from manure and spent bedding for an additional revenue stream. This strategy is used at the university farm where this study was conducted (Smith et al., 2016).

\section{Scenario 2: Animal Bedding Production for Profit}

Although producing bedding exclusively for the farm is a feasible option for larger operations or a cooperative of smaller farms, scenario 2 illustrates the more likely situation where the venture is profit driven and bedding is sold. Table 4 illustrates the economics of a wood shaving venture based on machine use per week, using the same 24 parameter values in scenario 1 .

As depicted in Table 4, the annual revenue during the loan period ranges from a loss of $\$(14,410)$ per year to $\$ 132,522$ when operating 8 to $40 \mathrm{~h} /$ wk. The implicit hour- 
Table 4. Financial performance if producing bedding for sale

Machine hours per week

\begin{tabular}{|c|c|c|c|c|c|}
\hline \multirow[b]{2}{*}{ Financial variables } & \\
\hline & 8 & 16 & 24 & 32 & 40 \\
\hline \multicolumn{6}{|l|}{ Loan period } \\
\hline Production (yd³/yr) & 3,796 & 7,592 & 11,388 & 15,184 & 18,980 \\
\hline Production ( $\left.\mathrm{m}^{3} / \mathrm{yr}\right)$ & 2,902 & 5,805 & 8,707 & 11,609 & 14,511 \\
\hline Cost $(\$ / y r)$ & 71,350 & 91,589 & 111,828 & 132,068 & 152,178 \\
\hline Revenue (\$/yr) & $(14,410)$ & 22,291 & 58,992 & 95,692 & 132,522 \\
\hline Implicit hourly wage (\$) & (35) & 27 & 47 & 58 & 64 \\
\hline \multicolumn{6}{|l|}{ After the loan period } \\
\hline Cost (\$/yr; operating) & 28,485 & 48,724 & 68,963 & 89,203 & 109,313 \\
\hline Revenue (\$/yr) & 28,455 & 65,156 & 101,857 & 138,557 & 175,387 \\
\hline Implicit hourly wage (\$) & 63 & 78 & 82 & 83 & 84 \\
\hline \multicolumn{6}{|l|}{ Summary at yr 15} \\
\hline Payback period & 19 yr $291 \mathrm{~d}$ & $6 \mathrm{yr} 313 \mathrm{~d}$ & $3 \mathrm{yr} 214 \mathrm{~d}$ & $2 \mathrm{yr} 55 \mathrm{~d}$ & 1 y $196 \mathrm{~d}$ \\
\hline Net present value $(\$)$ & 159,884 & 563,648 & 967,411 & $1,371,164$ & $1,777,435$ \\
\hline Discounted BCR ${ }^{1}$ & 0.84 & 2.95 & 5.07 & 7.19 & 9.31 \\
\hline
\end{tabular}

${ }^{1} \mathrm{BCR}=$ benefit-cost ratio.

ly wage for one worker is $\$(35)$ to $\$ 64 / \mathrm{h}$, respectively. After the loan period, annual revenue increases to $\$ 28,455$ to $\$ 175,387$, with an implicit wage of $\$ 63$ to $\$ 84 / \mathrm{h}$ when operating 8 to $40 \mathrm{~h} /$ wk. After $15 \mathrm{yr}$, the venture provides a favorable payback period, NPV, and BCR, whether operating 24 or $40 \mathrm{~h} / \mathrm{wk}$ (Table 4). However, the 8-h scenario does not generate enough wood shavings to cover costs.

An important point to mention is that the output from this scenario provides an implicit hourly wage, which is suited for a family run business, where a specific wage is not paid to employees. However, Table 5 illustrates the economics of this type of venture if 2 employees are hired to run the wood shaving venture and are each paid $\$ 15 / \mathrm{h}$.

If hiring 2 individuals to run the machine, the annual revenue during the loan period ranges from $\$(27,056)$ to $\$ 69,290$ when operating 8 to $40 \mathrm{~h} /$ wk. The implicit hourly wage for the business owner of the venture would be $\$(65)$ to $\$ 33 / \mathrm{h}$, respectively. After the loan period, annual revenue increases to $\$ 15,809$ to $\$ 112,155$, which is equivalent to an implicit wage of $\$ 38$ to $\$ 54 / \mathrm{h}$ for the business owner, when operating 8 to $40 \mathrm{~h} / \mathrm{wk}$. After $15 \mathrm{yr}$, the venture provides a favorable payback period, NPV, and BCR for

Table 5. Profit potential if producing shavings with employees receiving a wage

Machine hours per week

\begin{tabular}{|c|c|c|c|c|c|}
\hline Financial variables & 8 & 16 & 24 & 32 & 40 \\
\hline \multicolumn{6}{|l|}{ Loan period } \\
\hline Production (yd³/yr) & 3,796 & 7,592 & 11,388 & 15,184 & 18,980 \\
\hline Production ( $\mathrm{m}^{3} / \mathrm{yr}$ ) & 2,902 & 5,805 & 8,707 & 11,609 & 14,511 \\
\hline Cost $(\$ / y r)$ & 83,996 & 116,882 & 149,768 & 182,653 & 215,410 \\
\hline Revenue (\$/yr) & $(27,056)$ & $(3,002)$ & 21,052 & 45,107 & 69,290 \\
\hline Implicit hourly wage (\$) & $(65)$ & (4) & 17 & 27 & 33 \\
\hline \multicolumn{6}{|l|}{ Post loan period } \\
\hline Cost (\$/yr; operating) & 41,131 & 74,017 & 106,903 & 139,788 & 172,545 \\
\hline Revenue (\$/yr) & 15,809 & 39,863 & 63,917 & 87,972 & 112,155 \\
\hline Implicit hourly wage (\$) & 38 & 48 & 51 & 53 & 54 \\
\hline \multicolumn{6}{|l|}{ Summary at year 15} \\
\hline Payback period & $>15 \mathrm{yr}$ & 12 yr 152 d & $7 \mathrm{yr} 3 \mathrm{~d}$ & $4 \mathrm{yr} 291 \mathrm{~d}$ & $3 \mathrm{yr} 6 \mathrm{~d}$ \\
\hline Net present value $(\$)$ & 19,281 & 282,430 & 545,580 & 808,740 & $1,074,397$ \\
\hline Discounted BCR ${ }^{1}$ & 0.10 & 1.48 & 2.86 & 4.24 & 5.63 \\
\hline
\end{tabular}

${ }^{1} \mathrm{BCR}=$ benefit-cost ratio. 
scenarios operating 24 to $40 \mathrm{~h} / \mathrm{wk}$, even with 2 employees (Table 5). This contrasts with the 8 -h scenario, which has a discounted BCR of 0.10 . The 16 -h scenario is also unsuitable, as the venture does not generate revenue for the business owner until after the loan period.

When considering both examples under scenario 2, where profit is the primary objective, it is important to note that just because the venture can produce large volumes of wood shavings, does not mean there is sufficient demand locally to absorb that level of supply. If operating the machine for $40 \mathrm{~h} /$ wk throughout the year, roughly $14,500 \mathrm{~m}^{3}$ (18,980 cubic yards) of wood shavings could be produced. If the UNH ODRF represents the average-sized organic dairy farm in New England, it would take roughly 30 dairy farms to absorb this quantity of wood shavings. If looking at conventional dairies, it would require 25 average-sized farms. However, if the bedding were sold to other farm operations (equine, poultry, swine, and so on) or bagged and shipped greater distances, the feasibility of supporting a full-scale wood shaving venture becomes more realistic.

A second important consideration for those interested in selling wood shavings is that material being sold to dairy farms requires the logs to be debarked if the bedding is being used by lactating cows. This is because bark has been associated with supporting the spread of disease causing bacteria that can cause coliform mastitis (Maroney, 2005; Thomas, 2009). Bark may also contain imbedded dirt and sand, which would quickly dull the knives of the wood shaving machine. This not only costs in knife sharpening and replacement, but also the labor associated with removing and installing the knives. Furthermore, woody bedding contaminated with dirt can increase the occurrence of Klebsiella bacteria that can cause mastitis (Jones and Bailey 2009). Although debarking machines exist, most are well over $\$ 30,000$ used. The purchase of such a machine, combined with the fuel and labor to run it, would increase the cost of producing the shavings substantially.

In addition to debarking the logs, most dairy farmers require animal bedding to be kiln dried, especially woody bedding, which has been found to support mastitis-causing Klebsiella if wet or green (Schukken et al., 2005). Smith et al. (2001) also reported a higher incidence of Escherichia coli in dairy cattle when housed in wet or muddy pens. In addition to reducing the risk of mastitis, kiln-dried bedding also absorbs more urine and animal waste than airdried bedding. Experiments on urine absorption by the authors of this study (unpublished data) found that eastern white pine can absorb $411 \%( \pm 10 \%)$ of its weight when kiln dried to $10 \%$. This contrasts with air-dried eastern white pine bedding at 30\% moisture content, which had an absorption capacity of $271 \%( \pm 14 \%)$ of its weight. In addition to reducing bacterial populations, drier bedding also increases cow comfort. A study by Fregonesi et al. (2007) found that cows prefer dry bedding and will lie down $5 \mathrm{~h}$ more per day if the bedding is dry when compared with wet. Of the 129 New England dairy farmers surveyed by Smith et al. (2017), 63\% indicated that they require woody bedding to be kiln dried. Although this leaves $37 \%$ that may purchase green shavings, this low number could be problematic for an individual forecasting the sale of large volumes of wood shavings. If the business venture is geared toward the dairy industry, a drying system would have to be considered. However, the equine industry uses pine shavings as a primary bedding source, and having kiln-dried shavings is not as important as in the dairy industry. In some cases, air-dried shavings are preferred to kiln dried because there is reduced dust, which is more of a concern for horses than having slightly elevated moisture content (kiln dried at 10 to $12 \%$ vs. air-dried at $30 \%$ ). In this situation, the wood shavings producer could purchase a lower cost drying system that used ambient air versus more conventional systems that require a fuel source.

When considering the economic feasibility of scenario 2, the potential for large capital expenses beyond the wood shaving machine (delivery vehicle, storage facility, debarker, and drying system) may prove to be financially unrealistic for most individuals. However, this type of venture may prove to be suited toward regional milling operations. Milling operations are well suited for a wood shaving venture, because they already have industrial dry kilns capable of drying the bedding. This type of operation could also remove the bark off the logs, either through a debarker or by sawing off the outer layer. Some mills may even find it advantageous to remove the outer layers of knotfree wood for lumber and run the knotty core through the wood shaving machine, as the value of shavings may be higher than low grade lumber. Regional milling operations also have access to the necessary supply of pine needed to feed the machine, and some may already have trucks that can be used for delivery of shavings.

\section{Operational Recommendations Relating to Economic Feasibility}

After $3 \mathrm{yr}$ of producing wood shavings at the UNH ODRF, the authors of this study have several operational recommendations on how to make the system more financially viable. The first recommendation relates to material handling. During the first few months of operation, a tractor fork was used to load logs into the wood shaving machine hopper. This method was inefficient because removing individual logs from the large pile of stored pine proved to be labor intensive. Additionally, loading multiple logs at a time without them entering the machine hopper slightly crooked proved to be difficult. Importantly, crooked logs create airspace in between the logs in the hopper, reducing machine output. The solution to this problem was purchasing a skid steer grapple attachment. This made removing logs from the large pile very efficient. Logs could also be quickly and strategically placed within the hopper box, requiring only $3.5 \mathrm{~min}$ to load a hopper box with 5 to $8 \operatorname{logs}$ (Smith, 2016). The greater control of log placement when using the grapple also reduced the in- 
ternal airspace in between logs, increasing machine output efficiency (Smith, 2016). From an economic standpoint, a grapple, or hydraulic log loading deck, is worth the expense. For reference, the UNH ODRF purchased a grapple instead of a log loading deck because the grapple attachment could be used for other purposes on the farm.

A second recommendation relating to material handling pertains to how the shavings are discharged from the end of the wood shaving machine. In most cases, the shavings will simply discharge out the rear of the machine into a pile, unless a separate conveyor or blower attachment is purchased. At the UNH ODRF, a separate blower or conveyor attachment was not purchased initially. Instead, a tractor with a large bucket was placed at the rear of the machine, where it would collect the shavings, which were then moved and piled away from the machine. Although this method saved capital cost initially, it increased labor cost by requiring 2 individuals to run the machine versus 1. As with the grapple, having a separate conveyor or blower to stack the shavings, or load them for transport, is worth the expense.

\section{Additional Considerations and Limitations of the Study}

Although the model presented in this study is robust, allowing for variation between wood shaving machines, site variables, and so on, the output is only as good as the input parameter values. This can become problematic because some of the input variables (output, maintenance cost, knife longevity, fuel consumption) are available only from the various wood shaving machine manufacturers. Should they report best case scenarios, the model would likely overestimate production while underestimating cost. However, a possible solution to this limitation would be to request that the manufacture provide a reference to someone who is currently using the specific model of interest and cross validate operational performance for input values for the model.

A second limitation of the study relates to input variables that are not programed into the model but have an effect on the overall financial viability of the wood shaving venture. The first variable not addressed in the model is tax incentives. These were not incorporated into the model because they vary by geographic region and every individual's specific tax situation. However, for those in the United States, it should be noted that the overall economics of the wood shaving venture, and the numbers reported in the earlier scenarios, would look more positive after considering this variable. For instance, the model has a specific depreciation rate related to machine life but does not include the annual depreciation deduction one can take on machinery. Likewise, the model does not consider farmer tax incentives that include machinery and equipment deduction, farm wage deduction, farm expense deduction, repayment of loans, and others listed in IRS Publication 225. Additional tax incentives also exist if the individual is harvesting wood themselves. Forest management and harvesting qualifies for many tax credits and deductions that include timber depletion, reforestation, depreciation, forest management and protection, and so on (Wang, 2012). If harvesting from farm woodlots, even more tax deductions and incentives can be found under IRS Publication 225. Importantly, the degree to which these tax credits and deductions affect the financial viability of the operation are region and individual specific and, therefore, cannot be modeled easily.

Although tax incentives will likely increase the financial viability of the wood shaving venture, the potential need to kiln dry the shavings will add substantial cost to the operation. This model did not incorporate a drying system, due to the variability in systems and fuel sources. Additionally, some farmers will purchase air-dried bedding if the moisture content is below $30 \%$. The model also does not include a debarking machine. As mentioned previously, debarking the logs is necessary due to microbial concerns and wear on machinery from soil and sand imbedded in the material.

A final variable worth mentioning, which was not incorporated into the model, relates to how the bedding material will be sold with regard to the expansion factor between solid wood and shavings. Wood shavings are often sold on a volume basis, meaning the individual selling the material is also selling air. In this study, experimental results found an expansion factor of 5:1 between solid wood and shavings. However, this expansion factor was $48 \%$ less than the expansion factor reported by Salsco, a manufacturer of wood shaving machines in Cheshire, Connecticut (Salsco, 2017). The variability in the expansion factors likely relates to the physical nature of the shavings themselves. If producing thicker shavings, there is less surface area per unit of solid wood, which would reduce the expansion factor. Likewise, shavings with more of a curl will stack less efficiently on one another, increasing airspace and the expansion factor. What is important about this discussion is that the expansion factor has a tremendous effect on the overall economics of the operation; larger expansion factors result in more profit because output per unit of purchased wood increases.

\section{IMPLICATIONS}

An economic decision model for forecasting the feasibility of using a wood shaving machine to produce animal bedding was developed and tested using parameter values from the UNH ODRF. Due to high capital and operating costs, smaller dairies consistent of New England would not likely have a favorable payback period, if only producing bedding for on-site consumption. However, larger farm operations, a cluster of small farms sharing a trailer-mounted machine, or ventures (farm or forestry) planning on selling bedding would likely have a favorable payback. This has important management implications beyond the case study region, because producing animal bedding using a 
wood shaving machine could be used for a variety of farm operations (dairy, equine, poultry, swine, and so on), using several different tree species of various size and quality. Finally, the economic decision model will allow practitioners to input site and machine-specific parameters to assess the feasibility for their own operation.

\section{ACKNOWLEDGMENTS}

The authors of this study would like to thank Pat Cota, Zach Charewicz, and Tom Oxford for their assistance with operating the wood shaving machine. We would also like to thank Steve Eisenhaure from UNH's Office of Woodlands and Natural Areas for conducting the harvests at the ODRF that provided the wood for the study.

This work was partially funded by the New Hampshire Agricultural Experiment Station (NHAES). This is Scientific Contribution Number 2727. This work was supported by the USDA National Institute of Food and Agriculture McIntire Stennis NH00073-M Project (0231860). Research funding was also provided by USDA Sustainable Agriculture Research and Education (SARE) grants [LNE11313/38640-30418, and LNE15-344/38640-23777]. Sponsors of financial support were independent of data collection, analysis, and publication of this article.

\section{LITERATURE CITED}

Basnyat, B., and A. K. Bhattacharya. 2007. Can agroforestry contribute to livelihoods of people? The Nepalese experience. Page 415 in Forestry for the Next Decade. A. K. Bhattacharya, ed. Concept Publ., New Delhi, India.

Coder, K. D. 2011. Estimating Tree Stem and Branch Weight. WSFNR11-22. Warnell School Forest. Nat. Resour., Univ. Georgia, Athens.

Cubbage, F. W., J. A. Burgess, and B. J. Stokes. 1991. Cross-sectional estimates of logging equipment resale values. For. Prod. J. 10:16-22.

Fregonesi, J. A., D. M. Veira, M. A. G. von Keyserlingk, and D. M. Weary. 2007. Effects of bedding quality on lying behavior of dairy cows. J. Dairy Sci. 90:5468-5472.

Jones, G. M., and T. L. Bailey. 2009. Understanding the Basics of Mastitis. Virginia Cooperative Extension Publication 404-233. Virginia Coop. Ext., Blacksburg, VA.

Lynch, D. L., and K. H. Mackes. 2002. Opportunities for making wood products from small diameter trees in Colorado. Res. Rep. RMRSRP-37. US Dept. Agric. Forest Serv., Rocky Mountain Res. Stn., Fort Collins, CO.
Maroney, M. 2005. Coliform Mastitis. Milk Money Fact Sheet 04. Univ. Wisconsin, Madison, WI.

McBride, W. D., and C. Greene. 2009. Characteristics, costs, and issues for organic dairy farming. Economic Res. Rep. No. 82. ARSUSDA, Washington, DC.

Mead, D., and C. Smith. 2016. Principles of nutrient management for sustainable forest bioenergy production. Page 560 in Advances in Bioenergy: The Sustainability Challenge. P. Lund, J. A. Byrne, G. Berndes, and I. Vasalos, ed. John Wiley Sons, West Sussex, UK.

Salsco. 2017. Shaving processing equipment and knife grinder. Accessed May 1, 2017. http://www.salsco.com/products/shavings -processing-equipment.html.

Schukken, Y. H., L. L. Tikofsky, and R. N. Zadoks. 2005. Environmental control for mastitis prevention, milk quality and food safety. Page 110 in Mastitis in Dairy Production: Current Knowledge and Future Solutions. H. Hogeveen, ed. Wageningen Acad. Publ., the Netherlands.

Smith, M. M., J. D. Aber, and R. Rynk. 2016. Heat recovery from composting: A comprehensive review of system design, recovery rate and utilization. Compost Sci. Util. 1-12. https://doi.org/10.1080/ 1065657X.2016.1233082.

Smith, D., M. Blackford, S. Younts, R. Moxley, J. Gray, L. Hungerford, T. Milton, and T. Klopfenstein. 2001. Ecological relationships between the prevalence of cattle shedding Escherichia coli O157:H7 and characteristics of the cattle or conditions of the feedlot pen. J. Food Prot. 64:1899-1903.

Smith, M. M. 2016. Creating an economically viable, closed-system, energy-independent dairy farm through the on-farm production of animal bedding and heat capture from an aerated static pile heat recovery composting operation. PhD Diss. Univ. New Hampshire, Durham.

Smith, M. M., C. L. Simms, and J. D. Aber. 2017. Case Study: Animal bedding cost and somatic cell count across New England dairy farms: Relationship with bedding material, housing type, herd size, and management system. Prof. Anim. Sci. 33:616-626.

Thomas, H. S. 2009. The Cattle Health Handbook: Preventive Care, Disease Treatments and Emergency Procedures for Promoting the Well-Being of Your Beef or Dairy Herd. Storey Publ., North Adams, MA.

Thomas, M. G., and D. R. Schumann. 1993. Income opportunities in special forest products: Self-help suggestion for rural entrepreneurs. Agriculture Information Bulletin 666. US Dept. Agric. Forest Serv. Washington, DC.

USDA. 2012. Census of Agriculture. USDA, Washington, DC.

Wang, L. 2012. Federal income tax on timber: A quick guide for woodland owners. FS-1007. USDA Forest Serv., Washington, DC.

Woodall, C. W., W. G. Luppold, P. J. Ince, R. J. Piva, and K. E. Skog. 2012. An assessment of the downturn in the forest products sector in the northern region of the United States. For. Prod. J. 61:604-613. 